\title{
Extraction of unsaturated fatty acid-rich oil from common carp (Cyprinus carpio) roe and production of defatted roe hydrolysates with functional, antioxidant, and antibacterial properties
}

Ghelichi, Sakhi; Shabanpour, Bahareh; Pourashouri, Parastoo; Hajfathalian, Mona; Jacobsen, Charlotte

Published in:

Journal of the Science of Food and Agriculture

Link to article, DOI:

10.1002/jsfa. 8608

Publication date:

2018

Document Version

Peer reviewed version

Link back to DTU Orbit

Citation (APA):

Ghelichi, S., Shabanpour, B., Pourashouri, P., Hajfathalian, M., \& Jacobsen, C. (2018). Extraction of unsaturated fatty acid-rich oil from common carp (Cyprinus carpio) roe and production of defatted roe hydrolysates with functional, antioxidant, and antibacterial properties. Journal of the Science of Food and Agriculture, 98(4), 14071415. https://doi.org/10.1002/jsfa.8608

\section{General rights}

Copyright and moral rights for the publications made accessible in the public portal are retained by the authors and/or other copyright owners and it is a condition of accessing publications that users recognise and abide by the legal requirements associated with these rights.

- Users may download and print one copy of any publication from the public portal for the purpose of private study or research.

- You may not further distribute the material or use it for any profit-making activity or commercial gain

- You may freely distribute the URL identifying the publication in the public portal 
Extraction of unsaturated fatty acid-rich oil from common carp (Cyprinus carpio) roe and production of defatted roe hydrolysates with functional, antioxidant, and antibacterial properties

Running title: Common carp roe oil and functional, antioxidant, and antibacterial hydrolysate

Sakhi Ghelichi ${ }^{1}$, Bahareh Shabanpour ${ }^{1 *}$, Parastoo Pourashouri ${ }^{1}$, Mona Hajfathalian ${ }^{2}$, Charlotte Jacobsen ${ }^{2}$

${ }^{1}$ Department of Seafood Science and Technology, Faculty of Fisheries and Environmental Science, Gorgan University of Agricultural Sciences and Natural Resources, Gorgan, Iran

${ }^{2}$ Division of Food Technology, National Food Institute, Technical University of Denmark, 2800 Kgs. Lyngby, Denmark

*Corresponding author email: bshabanpour@yahoo.com

\begin{abstract}
BACKGROUND: Common carp roe is a rich protein and oil source, which is usually discarded with no specific use. The aims of this study were to extract oil from the discarded roe and examine functional, antioxidant, and antibacterial properties of defatted roe hydrolysates (CDRHs) at various degrees of hydrolysis (DH).
\end{abstract}

RESULTS: Gas chromatography (GC) of fatty acid methyl esters (FAMEs) revealed that common carp roe oil contained high level of unsaturated fatty acids. The results of high-

This article has been accepted for publication and undergone full peer review but has not been through the copyediting, typesetting, pagination and proofreading process, which may lead to differences between this version and the Version of Record. Please cite this article as doi: 10.1002/jsfa.8608 
performance liquid chromatography-mass spectrometry (HPLC-MS) indicated that enzymatic hydrolysis of defatted roe yielded higher content of essential amino acids. CDRHs displayed higher solubility than untreated defatted roe, which increased with DH. Better emulsifying and foaming properties were observed at lower DH and non-isoelectric points. Furthermore, water and oil binding capacity decreased with DH. CDRHs exhibited antioxidant activity both in vitro and in 5\% roe oil-in-water emulsions and inhibited the growth of certain bacterial strains.

CONCLUSION: Common carp roe could be a promising source of unsaturated fatty acids and functional bioactive agents. Unsaturated fatty acid-rich oil extracted from common carp roe can be delivered into food systems by roe oil-in-water emulsions fortified by functional, antioxidant, and antibacterial hydrolysates from the defatted roe.

Keywords: common carp (Cyprinus carpio), defatted roe hydrolysate, functional properties, antioxidant activity, fish roe oil-in-water emulsion, antibacterial activity.

\section{INTRODUCTION}

Recent biotechnological advances have opened a window into beneficial possibilities of value-added products from fish processing wastes. The wastes are envisaged as safe and potentially nutritious resources with high protein content and favourable pattern of essential amino acids. ${ }^{1}$ In this regard, enzymatic hydrolysis of fish processing wastes has provided a promising route toward achievement of bioactive agents ${ }^{2}$ and therefore, a higher market value. Furthermore, it can help prevent environmental pollution associated with fish 
processing waste mismanagement. Protein hydrolysates have been prepared from underutilized species, ${ }^{3,4}$ fish viscera and by-products, ${ }^{5,6,7}$ and fish roe ${ }^{8,9}$.

Antioxidant compounds are required to overcome the deteriorative effects of lipid oxidation such as cardiovascular disease, diabetes mellitus, nervous disorders, and even Alzheimer. ${ }^{10}$ Synthetic antioxidants, e.g. butylated hydroxyanisole (BHA), butylated hydroxytoluene (BHT), propyl gallate (PG), and tertiary butylhydroquinone (TBHQ), have been used as potent antioxidants in foodstuffs for decades; however, they are losing their popularity due to their potential adverse effects as well as the near-universal interest in natural products. ${ }^{11}$ Fish hydrolysate has been extensively considered for its antioxidant effect as a natural substitute for the industrial antioxidants. ${ }^{12}$

In addition to oxidation, food-borne disease caused by microorganisms is another major issue, especially in third-world and developing countries. ${ }^{13}$ These microorganisms might bring about major health-related complications through spoilage, toxins, and quality deterioration in foods. ${ }^{14}$ On the other hand, excessive use of antibiotics in foods may cause side-effects in addition to pathogen resistance. ${ }^{15}$ Protein hydrolysates have been shown to exert antibacterial effects; majority of the hydrolysates originated in milk proteins ${ }^{16}$ while some studies pointed to the possibility of obtaining antibacterial hydrolysates from marine resources. $^{17,18,19}$

Fish roe is considered a precious nutritional source due to its protein and oil content with high value of polyunsaturated fatty acids (PUFAs). ${ }^{20}$ However, this valuable source of unsaturated fatty acids is wasted upon heating and centrifuge during hydrolysis and thereby 
the possibility of using it in food preparations, nutraceuticals, supplements etc. is lost. Therefore, extraction of roe oil before hydrolysis could make it possible to make simultaneous use of both the protein and oil content of fish roe.

Common carp (Cyprinus carpio) is one of the most popular species for human consumption in Iran and the world. However, its roe is rarely consumed and is usually discarded with no specific use. In this study, common carp roe oil was extracted and its fatty acid composition was characterized. Hydrolysates were further prepared from the defatted roe and their composition and functional properties were determined. Furthermore, in vitro antioxidant activity of the hydrolysates was measured. Antioxidant activity of the hydrolysates was further evaluated in 5\% extracted oil-in-water emulsions. Finally, antibacterial effect of the hydrolysates towards certain gram-positive and -negative strains was determined.

\section{MATERIALS AND METHODS}

Chemicals

Alcalase 2.4 L FG (2.4 AU-A/g) was purchased from Novozymes (Bagsværd, Denmark). Butylated hydroxytoluene (BHT), ascorbic acid, ethylenediaminetetraacetic acid (EDTA), and 1,1-diphenyl-2-picrylhydrazyl (DPPH) were obtained from Sigma-Aldrich (Steinheim, Germany). Chloroform and methanol were of HPLC grade from Lab-Scan (Dublin, 
Ireland). All other chemicals and solvents were of analytical grade obtained from Merck (Darmstadt, Germany).

Oil extraction from fish roe

Fresh common carp roe was purchased from a public fish market in Gorgan, Iran. The roe was placed in polyethylene bag and stored at $-20{ }^{\circ} \mathrm{C}$ until extraction. Thawing was performed at ambient temperature with the aid of running water. Lipid extraction was performed following the Bligh and Dyer method $(1959)^{21}$ with slight modifications. ${ }^{22}$ The extracted oil was transferred into amber bottles, flushed with $\mathrm{N}_{2}$, and stored at $-40{ }^{\circ} \mathrm{C}$ until further experiments.

Fatty acid composition of common carp roe

Measurement of fatty acid composition of the lipid extracts was carried out through gas chromatography of fatty acid methyl esters (FAMEs). Bligh and Dyer (1959) lipid extracts were weighed in vials and were subsequently added with toluene and heptane with internal standard $(\mathrm{C} 23: 0)(400 \mu \mathrm{L}, 1: 3 \mathrm{v} / \mathrm{v})$. After a one-step methylation procedure using a microwave oven (Multiwave3000 SOLV, Anton Paar, Graz, Austria) with a 64MG5 rotor (5 min at $500 \mathrm{Watt}$ and 10 min cooling), the methyl esters were dissolved in $\mathrm{n}$-heptane at 20 $\mathrm{mg} / \mathrm{ml}$. FAMEs $(1.5 \mu \mathrm{g})$ were injected into an HP 5890A a gas chromatograph (Agilent Technologies, Palo Alto, CA, USA) in split mode (1:70) with a volume of $0.2 \mu \mathrm{L}$. The separation was done on a DB127-7012 column $(10 \mathrm{~m} \times$ ID $0.1 \mathrm{~mm} \times 0.1 \mu \mathrm{m}$; Agilent Technologies). Helium was used as carrier gas with a flow of $21 \mathrm{~cm} / \mathrm{sec}$. The injection and detection were performed at $250{ }^{\circ} \mathrm{C}$ and $240{ }^{\circ} \mathrm{C}$, respectively. The initial oven temperature 
was set at $160{ }^{\circ} \mathrm{C}$ and raised to $200{ }^{\circ} \mathrm{C}$; after $0.3 \mathrm{~min}$, it was again raised to $220{ }^{\circ} \mathrm{C}$; after 1 min, it was raised to $240{ }^{\circ} \mathrm{C}$ and kept at that temperature $3.8 \mathrm{~min}$; temperature increase was carried out at $10.6{ }^{\circ} \mathrm{C} / \mathrm{min}$. Methyl esters recognition was done through comparing the retention times of authentic standards. The peaks were integrated on PE Nelson software and fatty acids were quantified via comparing integrated areas. The fatty acids were expressed as area percentage of total fatty acids.

Preparation of defatted roe protein hydrolysate

Roe protein hydrolysate was prepared from the common carp defatted roe using Alcalase. Briefly, $5 \mathrm{gr}$ of the defatted roe was suspended in $150 \mathrm{ml}$ distilled water and mixed for 2 min. Thermal pre-treatment was done at $50^{\circ} \mathrm{C}$ for 15 min to inactivate endogenous enzymes. The reaction was initiated by adding Alcalase at $1.5 \%(\mathrm{v} / \mathrm{w})$ of protein content in the roe powder at $\mathrm{pH} 8$ and $50{ }^{\circ} \mathrm{C}$ for 30,60 , and $90 \mathrm{~min}$. The reaction was terminated in water bath at $90-100^{\circ} \mathrm{C}$ for $15 \mathrm{~min}$. The slurry was centrifuged at $13000 \mathrm{~g}$ at $4{ }^{\circ} \mathrm{C}$ for 30 min and supernatants were collected and stored at $-40^{\circ} \mathrm{C}$ until they were lyophilized in a Labconco freeze drying system (Kansas City, MO, USA). The common carp defatted roe protein hydrolysates were coded as CDRH-30, -60, and -90.

Characterisation of defatted roe and hydrolysates

Protein yield recovery and DH

The protein yield recovery for each hydrolysate was evaluated as the ratio of protein weight of lyophilized hydrolysates to the protein weight of defatted roe used as raw material. Following thermal inactivation of Alcalase, the reaction mixture was blended with one 
volume of $20 \%$ trichloracetic acid (TCA) and then centrifuged at $6700 \mathrm{~g}$ at $4{ }^{\circ} \mathrm{C}$ for $30 \mathrm{~min}$ to collect the $10 \%$ TCA-soluble materials. The DH of substrate (\%) was calculated as follows:

$\mathrm{DH}(\%)=\frac{10 \% \mathrm{TCA}-\text { soluble nitrogen in substrate }}{\text { total nitrogen in substrate }} \times 100$

Proximate composition

Moisture, ash and protein content were measured following the official methods of the AOAC (2006). ${ }^{24}$ In brief, moisture and ash content were gravimetrically determined by heating the samples until constant weight at $105{ }^{\circ} \mathrm{C}$ and $550{ }^{\circ} \mathrm{C}$, respectively. Protein content was determined by the Kjeldahl method by considering a nitrogen-to-protein conversion factor of 6.25. Lipid content was assessed following the method proposed by Bligh and Dyer (1959) ${ }^{21}$ with slight modifications using a reduced amount of chloroform and methanol. ${ }^{23}$

Sodium dodecyl sulphate polyacrylamide gel electrophoresis (SDS-PAGE) of hydrolysates

The protein composition of the hydrolysates was evaluated through SDS-PAGE by use of a precast NuPAGE 4-12\% Tris gel (Invitrogen, Carlsbad, CA) with MES running buffer (50 mM MES, $50 \mathrm{mM}$ Tris base, 0.1\% SDS, $1 \mathrm{mM}$ EDTA, $\mathrm{pH}$ 7.3). The hydrolysates were also run along with the different UF fractions. Samples with protein concentrations of $1 \mathrm{mg} / \mathrm{ml}$ were diluted 1:1 by SDS sample buffer (100 mM Tris $\mathrm{HCl} \mathrm{pH} 6.8,4 \%$ SDS, 0.2\% bromophenol blue, 10\% glycerol, $40 \mathrm{mM}$ dithiothreitol (DTT)) and boiled for $3 \mathrm{~min}$ at 100 ${ }^{\circ} \mathrm{C}$. Furthermore, Aliquots with $20 \mu \mathrm{g}$ of protein were injected into each well in the gel. For 
comparison purpose, SeeBlueplus2 (Invitrogen, Carlsbad, CA) prestained standards were selected. Electrophoresis was performed via the XCell SureLock ${ }^{\mathrm{TM}}$ Mini-Cell with a constant voltage of $200 \mathrm{~V}$ for $35 \mathrm{~min}$. The protein staining and destaining were carried out with Coomassie Brilliant blue R-250 for $18 \mathrm{~h}$ and ethanol:acetic acid (3:1), respectively.

Amino acid composition

Assessment of the amino acid composition was carried out by HPLC-MS following hydrolysis and derivatisation using EZ:faast Amino Acid Kit (Phenomenex, Torrance, CA, USA). The amino acid release was performed through hydrolysis using $6 \mathrm{M} \mathrm{HCl}$ for $1 \mathrm{~h}$ at $110{ }^{\circ} \mathrm{C}$ in a microwave sample preparation system (Multiwave 3000, Anton Paar GmbH, Graz, Austria). Afterwards, an aliquot of the sample was subjected to neutralization ( $\mathrm{pH}$ 1.5-5), purification by a solid phase extraction sorbent tip, and derivatisation followed by injection into Agilent HPLC 1100 (Santa Clara, CA, USA) coupled to an Agilent Ion Trap MS. Amino acids were separated at $35^{\circ} \mathrm{C}$ on a $250 \times 3.0 \mathrm{~mm}$ Zebron ZB-AAA column (Phenomenex, Torrance, CA, USA) via a gradient of $68-83 \% 10 \mathrm{mM}$ ammonium formate in methanol and $10 \mathrm{mM}$ ammonium formate in water at a flow rate of $0.5 \mathrm{~mL} / \mathrm{min}$. Positive ionization was acquired through APCI $\left(450{ }^{\circ} \mathrm{C}\right)$. Identification of compounds was done by comparing retention time and mass spectra of an external standard mixture. Calibration curves were prepared and analysed by HPLC-MS for quantification.

\section{Determination of functional properties}

Functional properties of the hydrolysates were determined by measuring solubility ${ }^{25}$, emulsifying activity index (EAI) and emulsion stability index (ESI) ${ }^{26}$, foam expansion (FE) 
and foam stability $(\mathrm{FS})^{27}$, water binding capacity $(\mathrm{WBC})^{28}$, and oil binding capacity $(\mathrm{OBC})^{29}$. Some modification were made in the measurement methods. ${ }^{13}$

Determination of antioxidant activity

In vitro Antioxidant effects

In vitro antioxidant activity of the hydrolysates was determined by measuring DPPH radical scavenging activity ${ }^{30}, \mathrm{Fe}^{2+}$ chelating activity ${ }^{31}$, and reducing power ${ }^{32}$. There were some modifications in order to measure $\mathrm{IC}_{50}$ values by drawing dose-response curves. ${ }^{23}$

Antioxidant activity in 5\% roe oil-in-water emulsions

CRDHs obtained from different reaction times were dissolved in distilled water (at a concentration of $2 \mathrm{mg}$ protein $/ \mathrm{ml}$ ) and the $\mathrm{pH}$ was adjusted to 7 . The solutions were stirred overnight at $5{ }^{\circ} \mathrm{C}$ using a magnetic stirrer for the protein rehydration. The $5 \%(\mathrm{w} / \mathrm{w})$ common carp roe oil-in-water emulsions were prepared by adding the roe oil gradually to the solutions during mixing at 16,000 rpm using an ultra turrax (T1500, Ystral, Dottingen, Germany). The roe oil was added during the first minute of mixing, and the total mixing time was $3 \mathrm{~min}$. Moreover, $100 \mu \mathrm{M} \mathrm{FeSO}_{4}(36.5 \mu \mathrm{L}$ per $65 \mathrm{~g}$ of emulsion) was added to emulsions in order to accelerate lipid oxidation. An emulsion without antioxidant (i.e. control) and another with $200 \mathrm{mg} / \mathrm{kg}$ of BHT were also prepared in order to make comparisons. Emulsions were stored in amber bottles at room temperature $\left(19-20{ }^{\circ} \mathrm{C}\right)$ in the dark for 4 days. Samples were taken at day 0, 1, 2, and 4 for lipid oxidation measurements. Antioxidant activity of the hydrolysates was determined by measuring peroxide value (PV), anisidine values (AV). PVs were measured on lipid extracts through the colorimetric 
ferricthiocyanate method at $500 \mathrm{~nm} \cdot{ }^{33}$ AVs were obtained according to AOCS Official Method Cd 18-90. ${ }^{34}$ Measurement of PVs and AVs were done in duplicate. Totox value was determined as follows:

Totox value $=(2 \times \mathrm{PV})+\mathrm{AV}$

Determination of antibacterial effects

Five gram-positive and four gram-negative bacterial species were selected as test microorganisms for measurement of antibacterial activity. The gram positive species included Staphylococcus aureus (ATCC 25923), Micrococcus luteus (ATCC 4698), Bacillus cereus (ATCC 11778), Listeria monocytogenes (ATCC 43251), and Enterococcus faecalis (ATCC 29212) while the gram negative bacteria were Escherichia coli (ATCC 25922), Pseudomonas aeruginosa (ATCC 27853), Klebsiella pneumoniae (ATCC 13883), Salmonella enterica (ATCC 43972).

Briefly, the samples were dissolved in distilled water to acquire solutions with concentration of $200 \mathrm{mg} / \mathrm{ml}$; the solutions were passed through a $0.22 \mu \mathrm{m}$ Nylon membrane filter. Culture suspensions $\left(10^{6} \mathrm{CFU} / \mathrm{ml}\right)$ were spread on Muller-Hinton agar. Then, three bores $(4 \mathrm{~mm}$ diameter) were loaded with $100 \mu \mathrm{l}$ of the hydrolysate solutions. In addition, one well was loaded with $100 \mu \mathrm{l}$ of sodium phosphate buffer as negative controls. After $1 \mathrm{~h}$ at $4{ }^{\circ} \mathrm{C}$, the Petri dishes were incubated for $24 \mathrm{~h}$ at $37^{\circ} \mathrm{C}$. Antibacterial activity was determined as the diameter of the clear zone of growth inhibition.

Statistical analysis 
Data analyses were performed via Analysis of Variance (ANOVA) and differences between means were determined by the Least Significant Difference (LSD) test with a confidence interval of $95 \%$. All the statistical operations were performed in the Statistical Package for the Social Sciences (SPSS) version 21.0 (SPSS Inc., USA). Differences were considered significant at $\mathrm{p}<0.05$.

\section{RESULTS AND DISCUSSION}

Fatty acid composition of the extracted oil

Common carp roe oil exhibited a desirable content of unsaturated fatty acids $\left(655.7 \mathrm{~g} \mathrm{~kg}^{-1}\right)$ (Data not shown). Both mono- and poly-unsaturated fatty acids were found to be more abundant than saturated fatty acids. $\sum$ MUFA, $\sum$ PUFA, and $\sum$ SAFA were $347.4 \mathrm{~g} \mathrm{~kg}^{-1}$, $308.3 \mathrm{~g} \mathrm{~kg}^{-1}, 270.6 \mathrm{~g} \mathrm{~kg}^{-1}$, respectively. Contents of PUFAs were in descending order: $\mathrm{n}-9>$ n-6 $>$ n-3 fatty acids. EPA (C20:5 n-3) and DHA (C22:6 n-3) accounted for $74.2 \mathrm{~g} \mathrm{~kg}^{-1}$ of the total fatty acids. The most abundant fatty acid in common carp roe oil was oleic acid (C18:1 n-9). Moreover, the main PUFA and SAFA were linoleic acid (C18:2 n-6) and palmitic acid (C16:0), respectively. In line with the results of the present study, it was reported that the predominant MUFA and SAFA in skipjack (K. pelamis) roe were oleic acid and palmitic acid, respectively; however, the main PUFA in that study was DHA. ${ }^{20}$ The variations in fatty acid composition of roe protein hydrolysates could be attributed to inter-species differences as well as fish farming and/or feeding conditions.

\section{Characterisation of CDRH}

Proximate composition and degree of hydrolysis 
Proximate composition of raw material and hydrolysates are shown in Table 1. Moisture in the hydrolysates was $<100 \mathrm{~g} \mathrm{~kg}^{-1}$, which is consistent with previous studies. ${ }^{23,35}$ The low level of moisture in the hydrolysates is due to high temperature during hydrolysis as well as lyophilization or spray drying at the end of process. ${ }^{36}$ The ash content in the hydrolysates was relatively high and close to $250 \mathrm{~g} \mathrm{~kg}^{-1}$. The relatively high content of ash in the hydrolysates can be explained by acid/base addition for the $\mathrm{pH}$ adjustment. ${ }^{36}$ The maximum protein content in the hydrolysates was close to $660 \mathrm{~g} \mathrm{~kg}^{-1}$, which is within the range of 600 $\mathrm{g} \mathrm{kg}^{-1}$ to $900 \mathrm{~g} \mathrm{~kg}^{-1}$ reported by previous studies. Higher protein content in hydrolysates than the defatted roe could be attributed to protein solubilisation during hydrolysis as well as removal of insoluble solid matter by centrifugation. ${ }^{36}$ Protein yield recovery ranged from circa $540 \mathrm{~g} \mathrm{~kg}^{-1}$ to $580 \mathrm{~g} \mathrm{~kg}^{-1}$. The protein recovery increased as the reaction progressed. As expected, lipid content in the hydrolysates was low, which is due to separation of lipids during centrifugation. It should be noted that lipid content of the raw material was also low because of the defatting process before hydrolysis. The considerable decrease in lipid content of hydrolysates is favourable since it can minimize the risk of lipid oxidation and formation of secondary oxidation products. ${ }^{37}$

The degree of hydrolysis increased with time of reaction. A rapid rate of hydrolysis was observed in the beginning of the process while it slowed down as hydrolysis progressed. This might be due to decrease in substrate molecules for enzyme reaction ${ }^{9}$ and formation of reaction products leading to limitation of enzyme activity. ${ }^{35}$ There was a direct relationship between DH and protein yield recovery.

Amino acid composition 
Glutamic acid and aspartic acid were the most predominant non-essential amino acids in defatted roe and hydrolysates (Table 2). This is because of the marine origin of the hydrolysates, which is consistent with previously reported studies. ${ }^{9,20,23,38}$ The most prevalent essential amino acids were leucine and arginine followed by lysine and valine, which is in agreement with previous analyses. ${ }^{20,36}$ Enzymatic hydrolysis led to increase in the ratio of essential to nonessential amino acids. Negligible amount of hydroxyproline was found in defatted roe and hydrolysates, which might be due to low content of collagen in common carp roe. Hydroxyproline accounts for the stability of the collagen helix. ${ }^{39}$ Methionine was also negligible in defatted roe; however, after the enzymatic hydrolysis, the content of this essential amino acid rose dramatically, reaching from $2.6 \mathrm{~g} \mathrm{~kg}^{-1}$ protein in the defatted roe to over $20 \mathrm{~g} \mathrm{~kg}^{-1}$ protein in the hydrolysates. Hydrolysis of defatted roe by Alcalase yielded a higher percentage of essential amino acids compared to defatted roe, which is in agreement with the results of a study on boarfish (C. aper) protein hydrolysate. $^{40}$ However, a previous study on protein hydrolysates from sardine (S. pilchardus) and small-spotted catshark (S. canicula) muscles reported a constant amino acid composition in raw protein and hydrolysates. ${ }^{23}$

\section{SDS-PAGE}

Proteolysis of the defatted roe by Alcalase altered high molecular weight proteins in common carp defatted roe into peptides of varying molecular masses, especially those with low molecular weight (Fig. 1). Since there were no major peaks in the represented molecular mass area for the hydrolysates, it is presumed that hydrolysis of defatted roe protein predominantly yielded peptides with very low molecular weight, which can reflect 
efficiency of the enzymatic hydrolysis. In the raw material, the proteins were within the range of 98-198 $\mathrm{kDa}$; however, there were minor peaks within the range of 3-14 $\mathrm{kDa}$, which might be due to formation of the low-molecular-weight peptides by autolytic processes and/or defatting process. There were also traces of peptides with varying molecular weights in the hydrolysates, especially in CDRH-30 and -60. It is evidently seen that the peptides with higher molecular weights disappear gradually with hydrolysis time so that CDRH-90 seems to contain the peptides weighing $>3 \mathrm{kDa}$. It should be noted that in addition to hydrolysis time, specificity and concentration of enzyme as well as the reaction temperature might influence on molecular weight of resulted peptides.

\author{
Functional properties \\ Solubility
}

Protein solubility of defatted roe and the hydrolysates within the $\mathrm{pH}$ range of 1-12 is depicted in Fig. 2. Evidently, enzymatic hydrolysis of common carp defatted roe considerably increased the protein solubility. This might be due to the release of peptides with smaller size and lower molecular weight as well as formation of carboxylic and amino groups from amino acids, leading to exposure of polar groups to neighbouring water molecules. ${ }^{12,13}$ It may further be explained by conversion of hydrophobic to hydrophilic groups through the formation of two-end carbonyl and amino groups. ${ }^{41}$ Moreover, protein solubility increased with higher degrees of hydrolysis, which could be attributed to smaller 
peptides produced as hydrolysis continues. Additionally, protein solubility of the samples decreased greatly at $\mathrm{pH} 4$ and 5; however, it increased again with higher $\mathrm{pH}$ values and peaked at alkaline conditions, which is in agreement with previously reported studies. ${ }^{42,43,44}$ Higher protein solubility at non-isoelectric points could be justified by either net positive or net negative charges of proteins at acidic or alkaline conditions, respectively; this leads to more distance among protein molecules via electrostatic repulsive force and consequently,

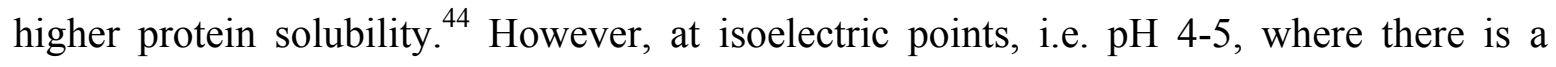
negligible protein charge, protein molecules aggregate as a result of strong intermolecular interactions. $^{45}$

\section{Emulsifying properties}

Table 3 represents the effects of hydrolysis time and $\mathrm{pH}$ on EAI $\left(\mathrm{m}^{2} / \mathrm{g}\right)$ and ESI ( $\left.\mathrm{min}\right)$ of CDRH. CDRH-30 and -60 exhibited the best EAI, whereas it decreased significantly $(\mathrm{p}<0.05)$ when the hydrolysis was prolonged to 90 minutes. The decreased EAI with hydrolysis time is due to higher degrees of hydrolysis achieved at prolonged hydrolysis. Higher EAI of the hydrolysates with lower DH can be attributed to a higher amount of larger molecular weight peptides as well as higher surface hydrophobicity. ${ }^{46}$ There was an antagonism between solubility and EAI of the hydrolysates at varying hydrolysis times, which is consistent with the results of a study on protein hydrolysates from surimi processing by-products. ${ }^{46}$ Reduction in emulsifying activity, despite higher solubility, of 
protein hydrolysates at higher $\mathrm{DH}$ is owing to the lower efficiency of shorter-length peptide chains to reduce interfacial tension. ${ }^{47}$ The same trend was detected for ESI, where emulsions' stability decreased as hydrolysis continued. The effect of $\mathrm{pH}$ was also determined on emulsifying properties of the hydrolysates. The worst EAI and ESI were identified at $\mathrm{pH} 5.0$, which is probably due to precipitation and/or lower net charge of large molecules in the hydrolysates at the isoelectric point (pI). ${ }^{46}$ In addition, decrease in ESI at pI can be explained by reduction in protein solubility. ${ }^{42}$

\section{Foaming properties}

FE and FS of the hydrolysates as influenced by hydrolysis time and $\mathrm{pH}$ are shown in Table 3. CDRH-30 exhibited the best FE although it was not significantly different from CDRH60 ( $>0.05)$, which can be explained by their very close degrees of hydrolysis (Table 1). However, as DH increased, foaming capacity of the hydrolysate with smaller peptides, i.e. CDRH-90, decreased significantly $(\mathrm{p}<0.05)$. This is consistent with the results of previous studies. ${ }^{46,48}$ They stated that larger molecular size and surface hydrophobicity of peptides in hydrolysates account for improved foaming properties. This is further supported here by better FS of the hydrolysates obtained at shorter hydrolysis times. Hydrophobic residues and decreased surface tension are responsible for flexibility of proteins and peptides, making them capable of quick settlement, unfolding, and rearrangement at the air-water interface and consequently, rendering better foaming properties to hydrolysates. ${ }^{48}$ It seems that the effect of high hydrophobicity of larger peptides in CDRH-30 and -60 on FE outweighed the capacity of smaller peptides in CDRH-90 to incorporate more air into the solution and raise $\mathrm{FE} .{ }^{47}$ 
Foaming properties of CDRH were also found to be reliant on $\mathrm{pH}$. The lowest FE and FS of the hydrolysates were detected at $\mathrm{pH} 5.0$, which might be due to the reduced net charge and the precipitation of the large protein molecules of the hydrolysates at isoelectric $\mathrm{pH} .{ }^{46}$ The hydrolysates in the present study had higher $\mathrm{FE}$ in acidic $\mathrm{pH}$, whereas the foams were more stable at alkaline $\mathrm{pH}$. These variations in foaming properties of the hydrolysates at varying $\mathrm{pH}$ might be attributed to different compositions and charges of peptides with different molecular sizes. ${ }^{46}$

Water and oil binding

WBC and $\mathrm{OBC}$ of the hydrolysates are represented in Table 3 . The relatively high WBC and $\mathrm{OBC}$ of the hydrolysates indicate that they can be adopted as functional additives in various food systems in order to avoid water and oil losses. Both WBC and OBC decreased significantly when the hydrolysis continued for 90 minutes. This is consistent with the results of previous studies. ${ }^{47,49}$ The decreased capacity of protein hydrolysates with higher DH to entrap water and oil may be justified by further disintegration of protein structure upon prolonged hydrolysis. ${ }^{50}$

\section{Antioxidant effect of CDRHs}

In vitro antioxidant activity of CDRHs

DPPH scavenging activity of the hydrolysates in the present study increased in a dosedependent manner (Fig. 3a). $\mathrm{IC}_{50}$ of CDRH-30 was $8 \mathrm{mg} / \mathrm{ml}$ whereas CDRH-60 and -90 were able to inhibit $50 \%$ of the free radical content when applied at 14 and $12.5 \mathrm{mg} / \mathrm{ml}$, respectively. DPPH scavenging activity decreased with DH, which is consistent with 
previous reports. ${ }^{23,48,51}$ However, there have been reports indicating that DPPH scavenging capacity increases with $\mathrm{DH}$; for instance, it was reported that peanut protein hydrolysate exhibited higher electron donation behaviour at higher $\mathrm{DH}^{43}$ These differences may be pertinent to amino acid composition of the hydrolysates, which is a function of the source of protein (animal, plant, etc.), adopted protease, and hydrolysis conditions. DPPH scavenging activity of CDRH-30 at $20 \mathrm{mg} / \mathrm{ml}$ exceeded that of BHT solution $(0.2 \mathrm{mg} / \mathrm{ml})$. The high radical scavenging activity of the hydrolysates could be explained by their high content of hydrophobic amino acids ${ }^{36}$ (Table 2). The results showed that common carp defatted roe protein hydrolysate, especially at lower $\mathrm{DH}$, is able to retard oxidative chain reactions caused by free radicals and therefore, can be considered a substitute for synthetic antioxidants.

$\mathrm{Fe}^{2+}$ chelating activity of CDRH increased dose-dependently (Fig. 3b). CDRH-90 exhibited the best chelating capacity, which was relatively similar to that of $0.5 \mathrm{mM}$ EDTA solution when evaluated at $2 \mathrm{mg} / \mathrm{ml}$. In contrast to the results obtained from DPPH scavenging assay, CDRHs displayed higher metal ion chelating activity with $\mathrm{DH}$. $\mathrm{IC}_{50}$ values of CDRH-30, -60 , and -90 were found to be $1.5,0.91$, and $0.8 \mathrm{mg} / \mathrm{ml}$, respectively. Higher $\mathrm{Fe}^{2+}$ chelating activity of CDRH-90 is presumably due to its higher content of aspartate and arginine (Table 2). Peptides containing carboxyl (e.g. Asp) and amino (e.g. Arg) groups at their side chains can contribute to chelation of metal ions. ${ }^{52}$ In addition to the content of amino acids, their position can also be an important factor in metal ion chelating activity of hydrolysates; for instance, His residues exhibit higher $\mathrm{Fe}^{2+}$ chelating capacity when located at $\mathrm{N}$ - rather than $\mathrm{C}$-terminus. ${ }^{51}$ The high chelating activity of the hydrolysates here, 
especially CDRH-90, is imperative because it can block transition metal ions; these ions may initiate lipid oxidation by decomposition of lipid hydroperoxides into peroxyl and alkoxyl. ${ }^{11}$

Reducing power is characterized by the potency of any given agent to reduce the $\mathrm{Fe}^{3+} /$ ferricyanide complex to ferrous form and therefore, it is an indicator of the agent's antioxidant activity. CDRHs displayed reducing power in a dose-dependent manner. When evaluated at $20 \mathrm{mg} / \mathrm{ml}$, CDRH-30 surpassed $0.5 \mathrm{mM}$ ascorbic acid solution in reducing power. The hydrolysates with lower DH had higher ability of donating electron to and neutralize $\mathrm{Fe}^{3+}$ (Fig. 3c), which is in agreement with previous reports. ${ }^{23,48}$ Furthermore, it was reported that hydrolysates of sardine and horse mackerel exhibited higher reducing power at lower DH. ${ }^{51}$

Antioxidant power in 5\% roe oil-in-water emulsions

The effect of adding CDRH on PV, AV, and Totox value of emulsions containing the oil extracted from common carp roe is represented in Fig. 4. Peroxide value rose in all the samples during the storage period. By the end of the first day of storage, all CDRHcontaining emulsions were able to delay PV development to the same extent as BHT, whereas thereafter the emulsion containing CDRH-90 displayed significantly higher PV than those fortified with CDRH-30 and -60 as well as with BHT. Interestingly, CDRH-30 and -60 showed relatively better ability of retarding primary oxidation than BHT in the emulsions containing common carp roe oil. The strong antioxidant activity of CDRH-30 in fish roe oil-in water emulsion can be due to its high radical scavenging capacity as 
evidenced by in vitro assays (Fig. 3a and c). The variation in antioxidant activity of hydrolysates with varying DH is generally attributed to their different amino acid composition and sequence. ${ }^{53}$ Similar to PV, AV was similar in all the emulsions containing CDRH by the end of day 1. Thereafter, the emulsion containing CDRH-90 exhibited significantly lower AV than those containing hydrolysates with larger peptides. There was no significant difference between AV of the emulsions with CDRH-90 and BHT. The higher ability of CDRH-90 than CDRH-30 and -60 to retard secondary oxidation in fish roe oil-in-water emulsions may be owing to its very high chelating power. The higher PV of the emulsion with CDRH-90 could be explained by the ability of CDRH-90 to prevent the decomposition of lipid hydroperoxides to a higher degree than the other hydrolysates. Further investigation is required to shed light on the contribution of radical scavenging and metal ion chelating of hydrolysates to retard primary and secondary oxidations, respectively. The molecular weight of peptides should also be taken into account; small molecular weight peptides represent faster diffusion rate and antioxidant activity at the oilwater interface (Fig. 1) whereas larger peptides exhibit more amphiphilic areas leading to more stable emulsions. ${ }^{54}$ Taken together, Totox values indicate that CDRH can be employed as a natural antioxidant instead of synthetic ones in fish oil-in-water emulsions (Fig. 4c).

\section{Antibacterial effects}

All the hydrolysates exhibited antibacterial activity toward three gram-positive (i.e. S. aureus, M. luteus, and B. cereus) strains and one gram-negative (i.e. E. coli) strain, while they were unable to inhibit the growth of other strains (Table 4). Higher antibacterial 
activity of the hydrolysates toward gram-positive bacteria is consistent with the results of a study on protein hydrolysates from fish meat, which found that gram-negative bacteria represent more resistance to protein hydrolysates. ${ }^{13}$ Moreover, CDRH-90 displayed a better antibacterial activity. A previous study reported that antibacterial activity of protein hydrolysates is greatly affected by their $\mathrm{DH} .{ }^{15}$ It seems that smaller peptides obtained with prolonged hydrolysis (Fig. 1) had better ability of inhibiting the growth of certain bacterial strains.

\section{CONCLUSIONS}

The present study showed the possibility of obtaining MUFA- and PUFA-rich oil from common carp discarded roe as well as protein hydrolysates from the defatted roe. All the hydrolysates exhibited desirable solubility, emulsifying and foaming properties, and water and oil binding. Furthermore, the hydrolysates displayed appropriate levels of antioxidant activity both in vitro and in 5\% extracted oil-in-water emulsions. The hydrolysates also showed antibacterial activity towards three gram-positive strains and E. coli, with higher antibacterial power at higher DH. Overall, common carp discarded roe is potentially a favourable source of unsaturated-fatty-acid-rich oil and bioactive compounds.

CONFLICT OF INTEREST: The authors declare that there are no conflicts of interest.

\section{ACKNOWLEDGEMENTS}


Authors are thankful to Gorgan University of Agricultural Sciences and Natural Resources of Iran and The Technical University of Denmark to support this research.

\section{REFERENCES}

1. Ennaas N, Hammami R, Beaulieu L and Fliss I, Purification and characterisation of four antibacterial peptides from protamex hydrolysate of Atlantic mackerel (Scomber scombrus) by-products. Biochem Bioph Res Co 462: 195-200 (2015).

2. Harnedy PA and FitzGerald RJ, Bioactive peptides from marine processing waste and shellfish: A review. J Func Foods 4: 6-24 (2012).

3. García-Moreno PJ, Pérez-Gálvez R, Espejo-Carpio FJ, Muñío MM, Guadix A and Guadix EM, Lipid characterization and properties of protein hydrolysates obtained from discarded Mediterranean fish species. J Sci Food Agr 93: 3777-3784 (2013).

4. Ovissipour M, Rasco B, Ghorban Shiroodi S, Modanlow M, Gholami S and Nemati M, Antioxidant activity of protein hydrolysates from whole anchovy sprat (Clupeonella engrauliformis) prepared using endogenous enzymes and commercial proteases. J Sci Food Agr 93: 1718-1726 (2013).

5. Bhaskar N and Mahendrakar NS, Protein hydrolysate from visceral waste proteins of Catla (Catla catla): Optimization of hydrolysis conditions for a commercial neutral protease. Bioresour Technol 99: 4105-4111 (2008).

6. Balti R, Bougatef A, El-Hadj Ali N, Zekri D, Barkia A and Nasri M, Influence of degree of hydrolysis on functional properties and angiotensin I-converting enzymeinhibitory activity of protein hydrolysates from cuttlefish (Sepia officinalis) byproducts. J Sci Food Agr 90: 2006-2014 (2010). 
7. Pires $\mathrm{C}$, Clemente $\mathrm{T}$ and Batista I, Functional and antioxidative properties of protein hydrolysates from Cape hake by-products prepared by three different methodologies. $J$ Sci Food Agr 93: 771-780 (2013).

8. Intarasirisawat $\mathrm{R}$, Benjakul $\mathrm{S}, \mathrm{Wu} \mathrm{J}$ and Visessanguan $\mathrm{W}$, Isolation of antioxidative and ACE inhibitory peptides from protein hydrolysate of skipjack (Katsuwana pelamis) roe. J Func Foods 5: 1854-1862 (2013).

9. Chalamaiah M, Jyothirmayi T, Diwan PV and Kumar BD, Antioxidant activity and functional properties of enzymatic protein hydrolysates from common carp (Cyprinus carpio) roe (egg). J Food Sci Tech 52: 5817-5825 (2015).

10. Naqash SY and Nazeer RA, Antioxidant and functional properties of protein hydrolysates from pink perch (Nemipterus japonicus) muscle. J Food Sci Tech 50: 972-978 (2013).

11. Shahidi F and Zhong Y, Measurement of antioxidant activity. J Func Foods 18: 757781 (2015).

12. Halim NRA, Yusof HM and Sarbon NM, Functional and bioactive properties of fish protein hydolysates and peptides: A comprehensive review. Trends Food Sci Tech 51: 24-33 (2016).

13. Jemil I, Jridi M, Nasri R, Ktari N, Ben Slama-Ben Salem R, Mehiri M, Hajji M and Nasri M, Functional, antioxidant and antibacterial properties of protein hydrolysates prepared from fish meat fermented by Bacillus subtilis A26. Process Biochem 49: 963972 (2014).

14. Sokmen M, Serkedjieva J, Daferera D, Gulluce M, Polissiou M, Tepe B, Akpulat HA, Sahin F and Sokmen A, In vitro antioxidant, antimicrobial, and antiviral activities of 
the essential oil and various extracts from herbal parts and callus cultures of Origanum acutidens. J Agr Food Chem 52: 3309-3312 (2004).

15. Sila A, Nedjar-Arroume N, Hedhili K, Chataigné G, Balti R, Nasri M, Dhulster P and Bougatef A, Antibacterial peptides from barbel muscle protein hydrolysates: Activity against some pathogenic bacteria. LWT-Food Sci Technol 55: 183-188 (2014).

16. Abdel-Hamid M, Goda HA, De Gobba C, Jenssen H and Osman A, Antibacterial activity of papain hydrolysed camel whey and its fractions. Int Dairy $J$ 61: 91-98 (2016).

17. Jemil I, Abdelhedi O, Mora L, Nasri R, Aristoy MC, Jridi M, Hajji M, Toldrá F and Nasri M, Peptidomic analysis of bioactive peptides in zebra blenny (Salaria basilisca) muscle protein hydrolysate exhibiting antimicrobial activity obtained by fermentation with Bacillus mojavensis A21. Process Biochem 51: 2186-2197 (2016).

18. Wald M, Schwarz K, Rehbein H, Bußmann B and Beermann C, Detection of antibacterial activity of an enzymatic hydrolysate generated by processing rainbow trout by-products with trout pepsin. Food Chem 205: 221-228 2016.

19. $\mathrm{Pu} \mathrm{C}$ and Tang $\mathrm{W}$, Affinity and selectivity of anchovy antibacterial peptide for Staphylococcus aureus cell membrane lipid and its application in whole milk. Food Control 72: 153-163 (2017).

20. Intarasirisawat $\mathrm{R}$, Benjakul $\mathrm{S}$ and Visessanguan $\mathrm{W}$, Chemical compositions of the roes from skipjack, tongol and bonito. Food Chem 124: 1328-1334 (2011).

21. Bligh EG and Dyer WJ, A rapid method of total lipid extraction and purification. Can J Physiol Pharm 37: 911-917 (1959). 
22. Intarasirisawat $\mathrm{R}$, Benjakul $\mathrm{S}$, Visessanguan $\mathrm{W}$ and $\mathrm{Wu} \mathrm{J}$, Effects of skipjack roe protein hydrolysate on properties and oxidative stability of fish emulsion sausage. LWT-Food Sci Technol 58: 280-286 (2014).

23. García-Moreno PJ, Guadix A, Guadix EM and Jacobsen C, Physical and oxidative stability of fish oil-in-water emulsions stabilized with fish protein hydrolysates. Food Chem 203: 124-135 (2016).

24. AOAC, Official methods of analysis. Association of Official Analytical Chemists Inc., Arlington (2006).

25. Tsumura K, Saito T, Tsuge K, Ashida H, Kugimiya W and Inouye K, Functional properties of soy protein hydrolysates obtained by selective proteolysis. LWT-Food Sci Technol 38: 255-261 (2005).

26. Pearce $\mathrm{KN}$ and Kinsella JE, Emulsifying properties of proteins: evaluation of a turbidimetric technique. J Agr Food Chem 26: 716-723 (1978).

27. Shahidi F, Han XQ and Synowiecki J, Production and characteristics of protein hydrolysates from capelin (Mallotus villosus). Food Chem 53: 285-293 (1995).

28. Mac-Connel AA, Eastwood A and Mitchell WD, Physical characterisation of vegetable foodstuffs that could influence bowel function. J Sci Food Agr 25: 1457-1464 (1974).

29. Lin MJY, Humbert ES and Sosulski FW, Certain functional properties of sunflower meal products. J Food Sci 39: 368-370 (1974).

30. Shimada K, Fujikawa K, Yahara K and Nakamura T, Antioxidative properties of xanthan on the autoxidation of soybean oil in cyclodextrin emulsion. J Agr Food Chem 40: 945-948 (1992). 
31. Dinis TC, Maderia VM and Almeida LM, Action of phenolic derivatives (acetaminophen, salicylate, and 5-aminosalicylate) as inhibitors of membrane lipid peroxidation and as peroxyl radical scavengers. Arch Biochem Biophys 315: 161-169 (1994).

32. Oyaizu M, Studies on products of browning reactions: antioxidative activities of browning products of browning reaction prepared from glucosamine. Jpn J Nutr $\mathbf{4 4}$ : 307-315 (1986).

33. Shantha NC and Decker EA, Rapid, sensitive, iron-based spectrophotometric methods for determination of peroxide values of food lipids. J AOAC Int 77: 421-424 (1994).

34. AOCS, AOCS Official Method Cd 18-90. p-Anisidine Value. Champaign: AOCS Press (1998).

35. Ovissipour M, Abedian A, Motamedzadegan A, Rasco B and Safari R, The effect of enzymatic hydrolysis time and temperature on the properties of protein hydrolysates from Persian sturgeon (Acipenser persicus) viscera. Food Chem 115: 238-242 (2009).

36. Chalamaiah M, Dinesh Kumar B, Hemalatha R and Jyothirmayi T, Fish protein hydrolysates: Proximate composition, amino acid composition, antioxidant activities and applications: A review. Food Chem 135: 3020-3038 (2012).

37. Shahidi F, Han XQ and Synowiecki J, Production and characteristics of protein hydrolysates from capelin (Mallotus villosus). Food Chem 53: 285-293 (1995).

38. Je JY, Park SY, Hwang JY and Ahn CB, Amino acid composition and in vitro antioxidant and cytoprotective activity of abalone viscera hydrolysate. J Func Foods 16: $94-103$ (2015). 
39. Vitagliano L, Berisio R, Mazzarella L and Zagari A, Structural bases of collagen stabilization induced by proline hydroxylation. Biopolymers 58: 459-464 (2001).

40. Ojha KS, Alvarez C, Kumar P, O'Donnell CP and Tiwari BK, Effect of enzymatic hydrolysis on the production of free amino acids from boarfish (Capros aper) using second order polynomial regression models. LWT-Food Sci Technol 68: 470-476 (2016).

41. Betty M, Awuor OL, Kirwa ME and Jackim MF, Antioxidative and functional properties of Rastrineobola argentea (Dagaa) fish protein hydrolysate. Discourse Journal of Agric \& Food Sci 2:180-189 (2014).

42. Wu H, Wang Q, Ma, T and Ren J, Comparative studies on the functional properties of various protein concentrate preparations of peanut protein. Food Res Int 42: 343-348 (2009).

43. Jamdar SN, Rajalakshmi V, Pednekar MD, Juan F, Yardi V and Sharma A, Influence of degree of hydrolysis on functional properties, antioxidant activity and ACE inhibitory activity of peanut protein hydrolysate. Food Chem 121: 178-184 (2010).

44. Bučko S, Katona J, Popović L, Petrović L and Milinković J, Influence of enzymatic hydrolysis on solubility, interfacial and emulsifying properties of pumpkin (Cucurbita pepo) seed protein isolate. Food Hydrocoll 60: 271-278 (2016).

45. Chatterjee R, Dey TK, Ghosh M and Dhar P, Enzymatic modification of sesame seed protein, sourced from waste resource for nutraceutical application. Food Bioprod Process 94: 70-81 (2015). 
46. Liu Y, Li X, Chen Z, Yu J, Wang F and Wang J, Characterisation of structural and functional properties of fish protein hydrolysates from surimi processing by-products. Food Chem 151: 459-465 (2014).

47. Kristinsson HG and Rasco BA, Fish protein hydrolysates: Production, biochemical, and functional properties. Crit Rev Food Sci Nutr 40: 43-81 (2000).

48. Klompong V, Benjakul S, Kantachote D and Shahidi F, Antioxidative activity and functional properties of protein hydrolysate of yellow stripe trevally (Selaroides leptolepis) as influence by the degree of hydrolysis and enzyme type. Food Chem 102: 1317-1327 (2007).

49. Wasswa J, Tang J, Gu X and Yuan X, Influence of the extent of enzymatic hydrolysis on the functional properties of protein hydrolysate from grass carp (Ctenopharyngodon idella) skin. Food Chem 104: 1698-1704 (2007).

50. He S, Franco C and Zhang W, Functions, applications and production of protein hydrolysates from fish processing co-products (FPCP). Food Res Int 50: 289-297 (2013).

51. Morales-Medina R, Tamm F, Guadix A, Guadix EM and Drusch S, Functional and antioxidant properties of hydrolysates of sardine (S. pilchardus) and horse mackerel (T. mediterraneus) for the microencapsulation of fish oil by spray-drying. Food Chem 194: 1208-1216 (2016).

52. Elias RJ, Kellerby SS and Decker EA, Antioxidant activity of proteins and peptides. Crit Rev Food Sci Nutr 48: 430-441 (2008).

53. Farvin SKH, Andersen LL, Nielsen HH, Jacobsen C, Jakobsen G, Johansson I and Jessen F, Antioxidant activity of cod (Gadus morhua) protein hydrolysates: In vitro 
assays and evaluation in 5\% fish oil-in-water emulsion. Food Chem 149: 326-334 (2014).

54. Rahali V, Chobert JM, Haertle T and Gueguen J, Emulsification of chemical and enzymatic hydrolysates of $\beta$-lactoglobulin: characterisation of the peptides adsorbed at the interface. Nahrung 44: 89-95 (2000). 
Table 1. Proximate composition, degree of hydrolysis, and protein yield recovery of common carp defatted roe and lyophilized hydrolysates

\begin{tabular}{ccccc}
\hline & Defatted roe & CDRH-30 & CDRH-60 & CDRH-90 \\
\hline Moisture $\left(\mathbf{g ~ k g}^{-1}\right)$ & $688.4 \pm 0.9^{\mathrm{a}}$ & $83.5 \pm 4.1^{\mathrm{b}}$ & $71.0 \pm 1.2^{\mathrm{b}}$ & $66.4 \pm 0.6^{\mathrm{b}}$ \\
\hline Protein $\left.\mathbf{g ~ k g}^{-1}\right)$ & $267.9 \pm 7.6^{\mathrm{b}}$ & $643.1 \pm 5.1^{\mathrm{a}}$ & $651.2 \pm 27.4^{\mathrm{a}}$ & $659.4 \pm 14.9^{\mathrm{a}}$ \\
\hline Lipid $\left(\mathbf{g ~ k g}^{-1}\right)$ & $13.6 \pm 2.0^{\mathrm{a}}$ & $12.1 \pm 1.0^{\mathrm{a}}$ & $11.3 \pm 1.1^{\mathrm{a}}$ & $10.7 \pm 1.0^{\mathrm{a}}$ \\
\hline Ash $\left(\mathbf{g ~ k g}^{-1}\right)$ & $11.9 \pm 0.4^{\mathrm{b}}$ & $254.5 \pm 1.0^{\mathrm{a}}$ & $256.9 \pm 0.9^{\mathrm{a}}$ & $258.9 \pm 0.5^{\mathrm{a}}$ \\
\hline $\begin{array}{c}\text { Protein yield } \\
\text { recovery, \% }\end{array}$ & - & 53.94 & 57.47 & 58.29 \\
\hline $\begin{array}{c}\text { Degree of } \\
\text { hydrolysis, \% }\end{array}$ & - & 4.32 & 4.75 & 5.93 \\
\hline
\end{tabular}

Results are the average of duplicate determinations \pm standard deviation. CDRH-30, -60 , and -90 : common carp defatted roe protein hydrolysed for 30,60 , and 90 min, respectively; the superscripts ' $a$ ' and ' $b$ ' indicate significant differences among the samples.

This article is protected by copyright. All rights reserved. 
Table 2: Amino acid composition of common carp defatted roe and lyophilized hydrolysates

\begin{tabular}{ccccc}
\hline & Defatted roe & CDRH-30 & CDRH-60 & CDRH-90 \\
\hline ARG & $60.1 \pm 0.3$ & $59.6 \pm 4.6$ & $51.4 \pm 2.4$ & $67.5 \pm 3.6$ \\
\hline HIS & $12.4 \pm 0.4$ & $15.1 \pm 0.3$ & $15.1 \pm 0.9$ & $14.1 \pm 0.0$ \\
\hline ILE & $44.7 \pm 1.1$ & $45.9 \pm 0.6$ & $51.1 \pm 3.7$ & $44.4 \pm 2.5$ \\
\hline LEU & $72.4 \pm 1.1$ & $74.7 \pm 1.5$ & $76.9 \pm 2.1$ & $76.1 \pm 3.2$ \\
LYS & $51.2 \pm 1.7$ & $52.6 \pm 2.7$ & $49.3 \pm 0.5$ & $48.4 \pm 0.9$ \\
\hline MET & $2.6 \pm 0.2$ & $25.0 \pm 0.0$ & $24.5 \pm 0.9$ & $20.7 \pm 0.3$ \\
\hline PHE & $35.1 \pm 0.3$ & $38.9 \pm 0.8$ & $40.7 \pm 1.8$ & $38.9 \pm 1.0$ \\
\hline THR & $31.9 \pm 0.7$ & $34.8 \pm 0.3$ & $35.7 \pm 0.6$ & $36.1 \pm 1.6$ \\
\hline VAL & $46.9 \pm 1.1$ & $47.5 \pm 0.5$ & $52.3 \pm 2.3$ & $46.1 \pm 1.6$ \\
\hline ALA & $67.8 \pm 2.6$ & $66.5 \pm 3.0$ & $68.1 \pm 0.1$ & $69.4 \pm 5.3$ \\
\hline ASP & $107.3 \pm 1.6$ & $110.4 \pm 1.9$ & $110.0 \pm 3.9$ & $114.0 \pm 2.6$ \\
\hline CYC & $6.7 \pm 0.1$ & $7.3 \pm 0.5$ & $7.6 \pm 0.6$ & $7.8 \pm 0.2$ \\
\hline HYP & $2.5 \pm 0.2$ & $2.1 \pm 0.0$ & $2.1 \pm 0.1$ & $2.8 \pm 0.1$ \\
\hline GLY & $45.5 \pm 1.5$ & $42.7 \pm 2.3$ & $43.5 \pm 0.7$ & $41.7 \pm 1.2$ \\
\hline GLU & $289.1 \pm 12.6$ & $243.5 \pm 6.6$ & $235.1 \pm 2.2$ & $237.8 \pm 7.2$ \\
\hline PRO & $48.5 \pm 0.7$ & $51.4 \pm 1.1$ & $55.6 \pm 0.9$ & $49.2 \pm 1.4$ \\
\hline SER & $49.6 \pm 0.7$ & $50.5 \pm 1.5$ & $48.0 \pm 2.4$ & $53.3 \pm 2.4$ \\
\hline TYR & $24.1 \pm 0.7$ & $30.5 \pm 1.9$ & $32.2 \pm 0.6$ & $30.8 \pm 0.9$ \\
\hline EAA & $357.3 \pm 6.9$ & $394.1 \pm 11.3$ & $397.0 \pm 15.2$ & $392.3 \pm 14.7$ \\
\hline NEAA & $641.1 \pm 20.7$ & $604.9 \pm 18.8$ & $602.2 \pm 11.5$ & $606.8 \pm 21.3$ \\
\hline EAA/NEAA & 0.55 & 0.65 & 0.65 & 0.64
\end{tabular}

Results are the average of duplicate determinations \pm standard deviation. CDRH-30, -60 , and -90 : common carp defatted roe protein hydrolysed for 30, 60, and 90 min, respectively; EAA: essential amino acids; NEAA: nonessential amino acids. No significant difference was observed among the samples in terms of amino acids $(\mathrm{p}>0.05)$.

This article is protected by copyright. All rights reserved. 
Table 3. Emulsifying activity index (EAI, $\mathrm{m}^{2} / \mathrm{g}$ ), emulsion stability index (ESI, min), foam expansion (FE, \%), foam stability (FS, \%), water binding capacity (WBC, g/g), and oil binding capacity $(\mathrm{OBC}, \mathrm{g} / \mathrm{g})$ of common carp defatted roe protein hydrolysates at varying hydrolysis times and $\mathrm{pH}$.

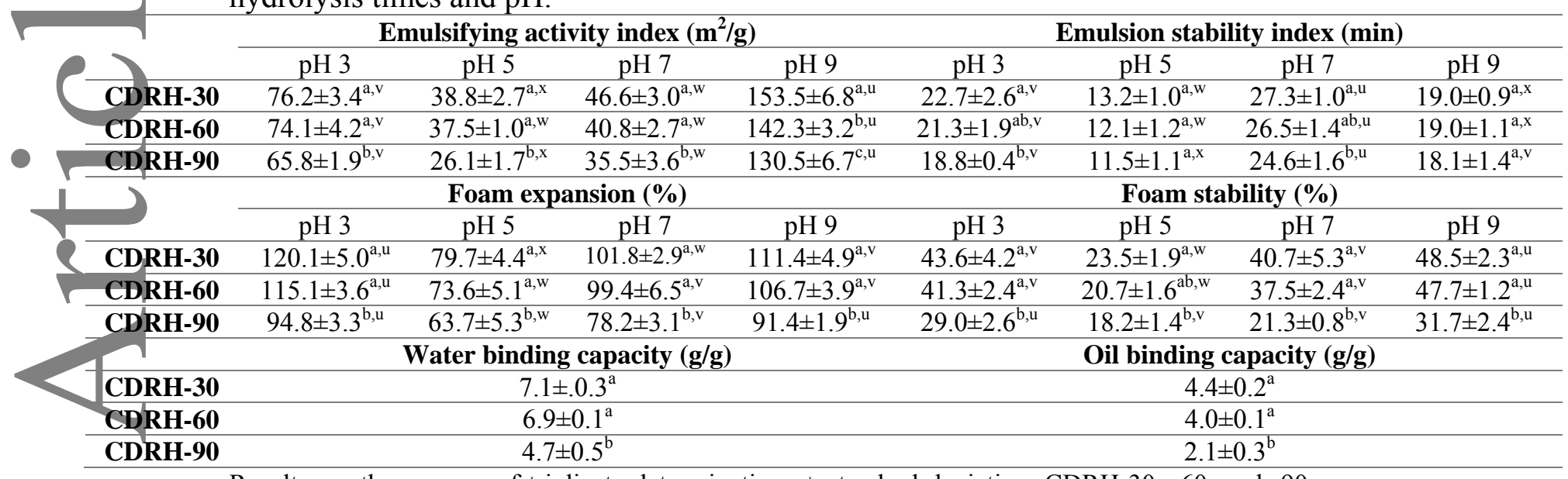

Results are the average of triplicate determinations \pm standard deviation. CDRH-30, -60, and -90: common carp defatted roe protein hydrolysed for 30, 60, and 90 min, respectively; The superscripts ' $a$ ', 'b', and ' $c$ ' indicate significant differences among the hydrolysates, and the superscripts ' $u$ ', ' $v$ ', ' $w$ ', and ' $x$ ' indicate significant differences among different $\mathrm{pH}$ values for a given sample. Same superscripts: no significant difference.

This article is protected by copyright. All rights reserved. 
Table 4. Antibacterial activity of common carp defatted roe protein hydrolysates at varying hydrolysis times.

\begin{tabular}{|c|c|c|c|}
\hline & CDRH-30 & CDRH-60 & CDRH-90 \\
\hline \multicolumn{4}{|l|}{ Gram-positive bacteria } \\
\hline S. aureus & + & + & ++ \\
\hline M. luteus & + & + & +++ \\
\hline B. cereus & ++ & ++ & ++ \\
\hline L. monocytogenes & - & - & - \\
\hline E. faecalis & - & - & - \\
\hline \multicolumn{4}{|l|}{ Gram-negative bacteria } \\
\hline E. coli & + & ++ & ++ \\
\hline P. aeruginosa & - & - & - \\
\hline K. pneumoniae & - & - & - \\
\hline S. enterica & - & - & - \\
\hline
\end{tabular}

This article is protected by copyright. All rights reserved. 


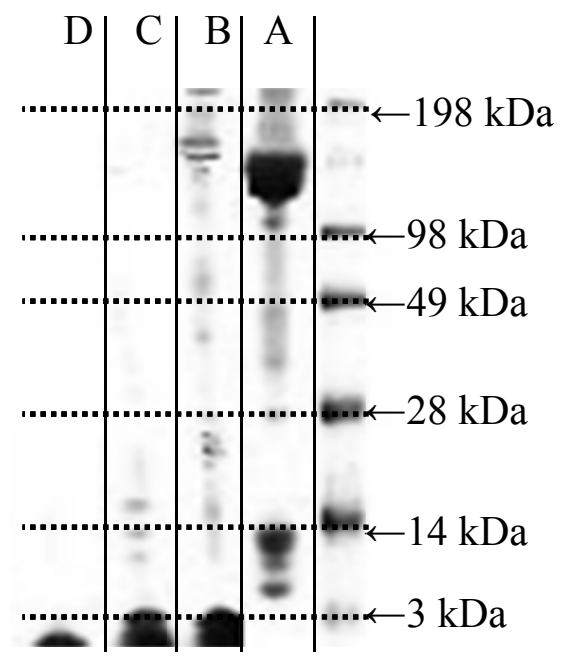

Figure 1. Electrophoretic pattern of common carp defatted roe and its protein hydrolysates; A: Defatted roe; B: CDRH-30; C: CDRH-60; and D: CDRH-90; numbers indicate reaction times. 


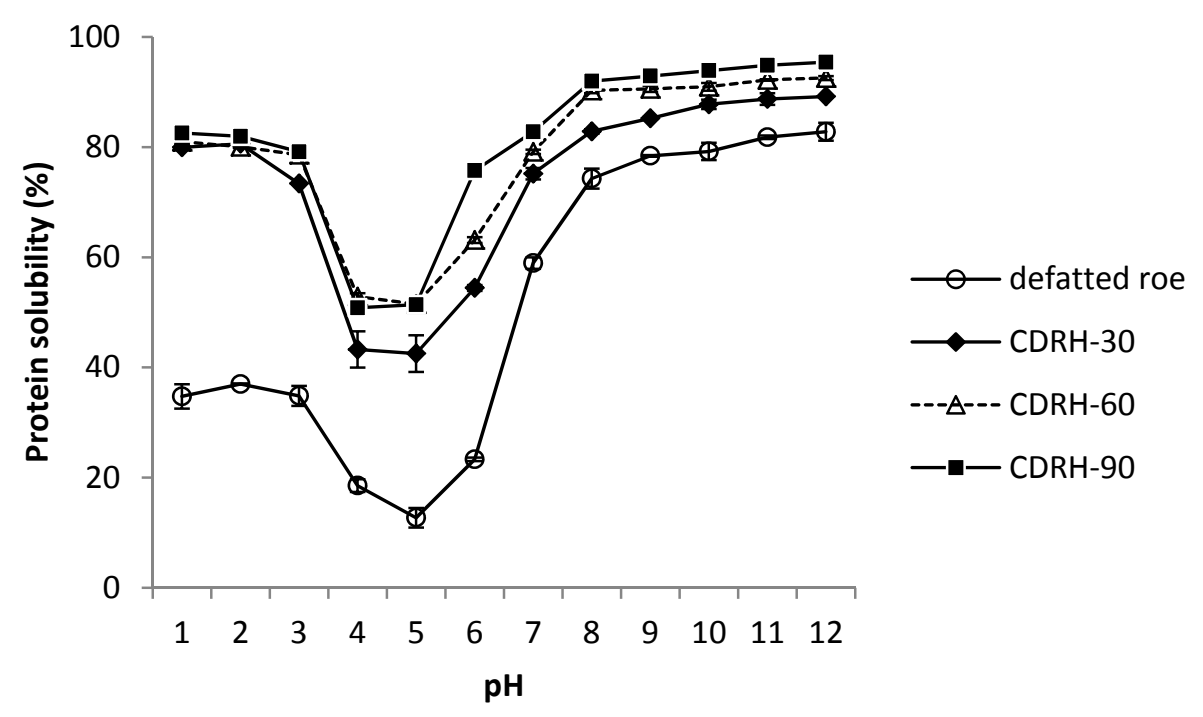

Figure 2. Solubility (\%) of defatted roe and its protein hydrolysates at varying $\mathrm{pH}$. The values represent the mean of triplicate measurements. Results are the average of triplicate determinations \pm standard deviation. CDRH-30, -60, and -90: common carp defatted roe protein hydrolysed for 30, 60, and 90 min, respectively. 


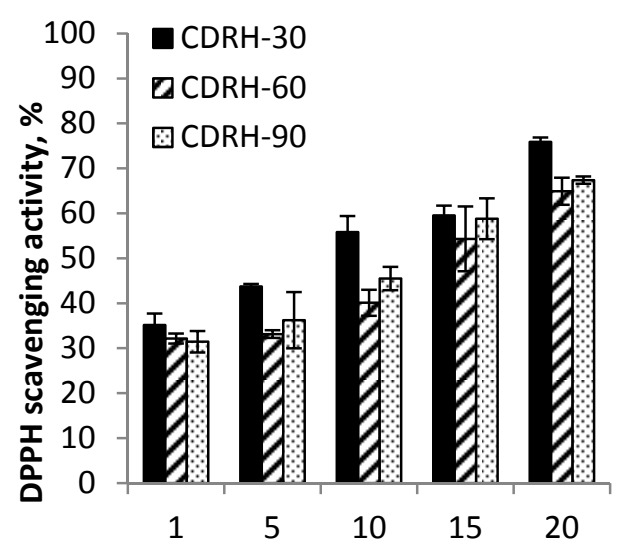

(a) concentration of hydrolysates, $\mathrm{mg} / \mathrm{ml}$

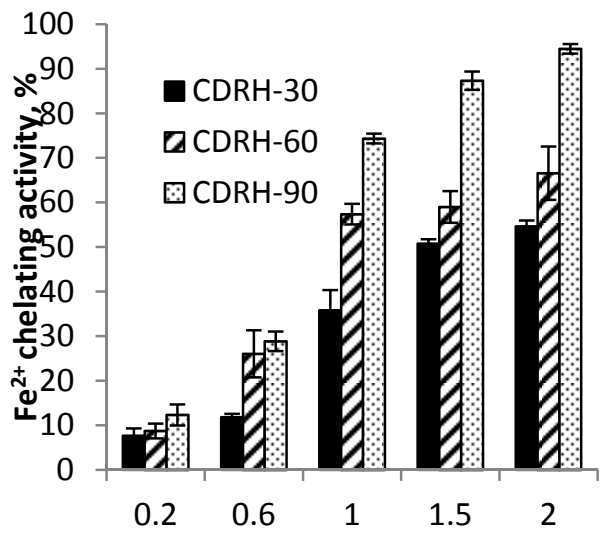

(b) concentration of hydrolysates, $\mathrm{mg} / \mathrm{ml}$

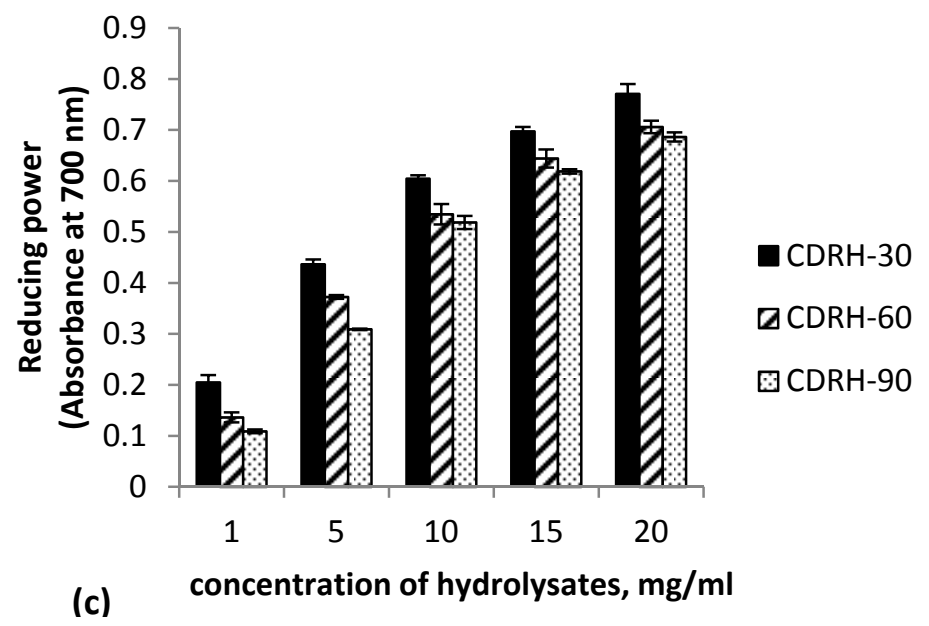

Figure 3. Antioxidant activity of common carp defatted roe hydrolysates: (a) DPPH radical scavenging activity; (b) $\mathrm{Fe}^{2+}$ chelating activity; (c) reducing power. Results are the average of triplicate determinations \pm standard deviation. CRDH: common carp defatted roe protein hydrolysate; the numbers indicate the reaction times. 


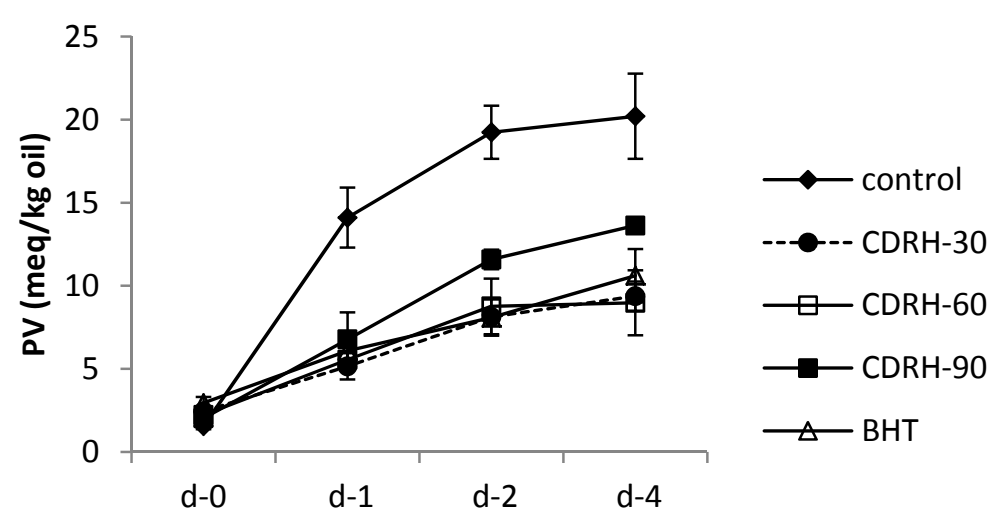

(a)

storage time in day(s)

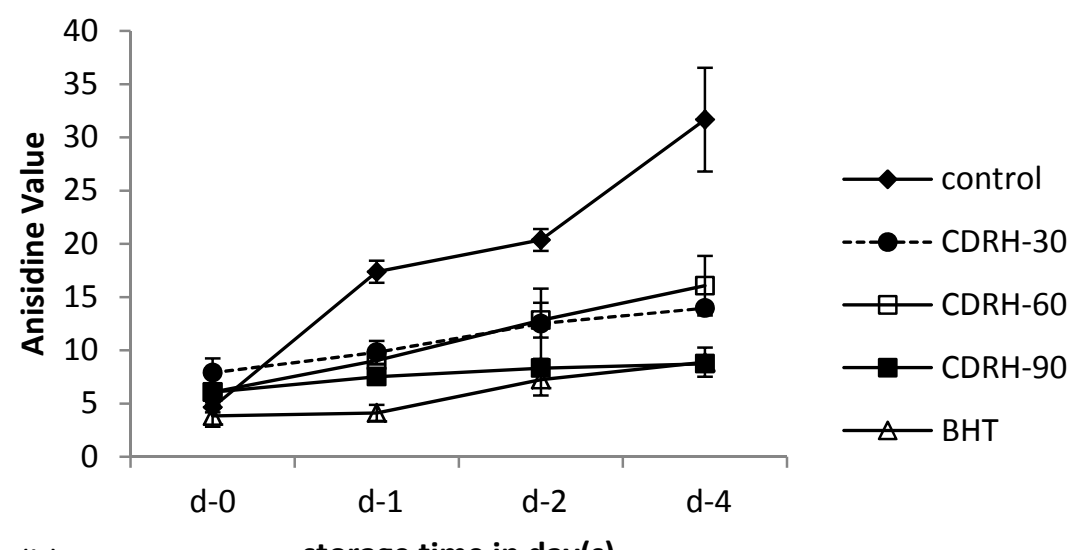

(b)

storage time in day(s)

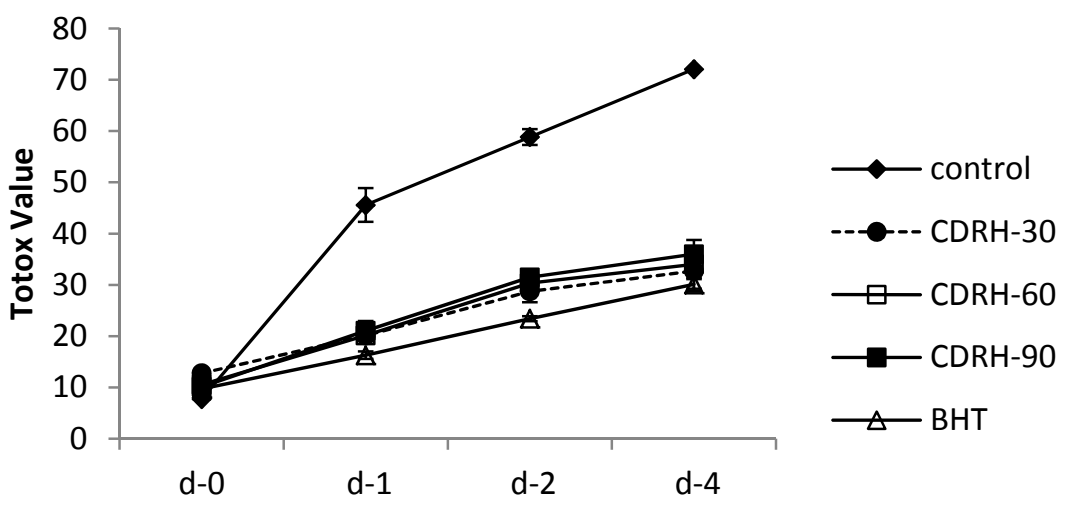

(c)

storage time in day(s)

Figure 4. Antioxidant activity of common carp defatted roe hydrolysates in 5\% common carp roe oil-in-water emulsions containing $100 \mu \mathrm{M}$ FeSO4 as oxidation inducer; (a) peroxide value, (b) anisidine value, and (c) Totox value. 